\title{
加速器の低エミッタンス電子銃開発の動向
}

\author{
栗 木 雅 夫*1
}

\section{Recent Developments of Low-emittance Electron Gun for Accelerator}

\author{
Masao KURIKI*1
}

${ }^{* 1}$ Graduate school of Advanced Sciences of Matter, Hiroshima University, 1-3-1 Kagamiyama, Higashihiroshima 739-8530, Japan

(Received July 1, 2011, Accepted September 28, 2011)

\begin{abstract}
Recent developments of low-emittance electron guns for accelerator are reviewed. In the accelerator field, DC biased triode thermionic gun (Pierce type gun) has been widely used and is still conventional. On the other hand, because of strong demands on the high brightness electron beam by FEL and other advanced accelerator concepts based on linear accelerator, the low emittance beam generation becomes one of the most important issue in the accelerator science. The R\&D effort is "accelerated" by two technological innovations, photo-cathode and RF gun. They made a large improvement on the beam emittance. After the explanations on the technical and physical aspects of the low emittance electron beam generation, advanced electron sources for accelerators are reviewed.
\end{abstract}

\section{1. はじめに}

電子加速器はその名のとおり電子を加速する装置で, 大き く分けると入射部と主加速器部からなる。主加速器部ではほ ぼ例外なく高周波加速を行うので, ビームの進行方向の長さ （バンチ長と呼び，しばしば時間でこれを表現する）は加速 高周波の周期に対して十分に短くなければならない，入射部 の役割は高周波加速が可能な短バンチの電子ビームを供給す ることにある. 入射部の中で, 電子を発生するためのデバイ スを電子銃と呼ぶ.

電子銃として熱陰極を使用した三極管構造の静電型電子 銃1)が長年にわたり標準的に用いられてきており，またそれ は今でも事実上の標準となっている. 現代の代表的な加速器 と言えば，原子核・素粒子実験に打ける衝突型加速器 $\left(\mathrm{CERN}\right.$ の $\left.\mathrm{LEP}^{2}\right), \mathrm{KEK}$ のトリスタン3)や $\mathrm{KEKB}^{4)}$ など）や 現在では多くの国々で稼働している放射光源（日本国内では $\mathrm{KEK}-\mathrm{PF}^{5)}$, SPring8 $8^{6}$ 等) である。これらの加速器はいず れも蓄積リング型の加速器である. 蓄積リングに入射する ビームは多くの場合線形加速器で加速され，リングへと入射 される. その後，リングの中を電子ビームは周回軌道をひた すらまわり続ける。 また電子はシンクロトロン放射によるエ ネルギー損失と，それを補う $\mathrm{RF}$ 空洞での再加速を繰り返す ので, 最終的なリング中での電子ビームの位相空間分布や工 ネルギー広がり，バンチ長などはリングの中におけるビーム 力学的な二つの競合過程, 量子励起と放射減衰の均衡状態々 して決定される7). 結果として, リング中で実現される電子 ビームの品質は入射電子ビームの性能とは全く独立に決まっ てしまう。したがって入射ビームの性能の向上は蓄積ビーム の品質向上に全く寄与しない。三極管構造の熱電子銃が事実 上の標準として長年使用されているのは，そのような技術的 要請が無かったからに他ならない。決して開発研究を意って きたからではない。

しかし近年, 線形加速器をべースとした新しいタイプの加 速器が多数建設されている. FEL (Free Electron Laser) ${ }^{8)}$

*1 広島大学先端物質科学研究科( 干739-853 広島県東広島市鏡山 1-3-1)
はその代表である．FELはエネルギー広がり，バンチ長， エミッタンズ1の小さい電子ビームを線形加速器で加速し, アンジュレーターという交番磁場でコヒーレントな放射光を 発生させるものである. 理研播磨 ${ }^{9)}$, ドイツの DESY(10), 米 国のスタンフォード線形加速器センター11)各々で $\mathrm{X}$ 線領域 の大型 FELの建設が進められ, 稼働を始めている. また電 子ビームとレーザーによる Laser Compton 散乱による疑単 色 $\mathrm{X}$ 線/ガンマ線の生成 ${ }^{12)}, \mathrm{RF}$ 電子銃などのビームによる 高速電子線回折 ${ }^{13)}$, 光カソードを用いた時間分解透過型電 子顕微鏡14)など, 小型の線形加速器でも様々な利用法が模 索されている. 電子銃で生成されたビームは線形加速器で加 速される際に，断熱減衰とよばれる相対論的効果によりエミ ッタンスを減少させる. 最終的に得られるビームのエミッタ ンスは電子銃での生成時の值を加速エネルギーでスケールし たものである.すなわち, 線形加速器から得られる電子ビー ムの品質は入射ビームに強く依存する. 線形加速器の高度利 用が進めば進むほど入射ビームの品質が意識され，電子銃に も低エミッタンス化が要求されるのである.

以上のように, 加速器の利用形態についての変遷を背景と して，低エミッタンスビーム生成というものがにわかに注目 をあびることとなっている，以下，低エミッタンスビーム生 成について概説し, 続いて研究開発の現状について述べる.

\section{2. 低エミッタンスビームの生成}

電子ビームは熱電子放出, 電界放出, そして光電効果等に より得られるが, 加速器の電子発生には熱電子放出と光電効 果がよく用いられる.

物質を高温に熱すると, 電子が真空中に放出される現象が 観測される.これを熱電子発生といい，この原理を用いた陰

†1 加速器ではビームの性質を示すのにエミッタンスを用いる．エ ミッタンスとは力学的には六次元位相空間における粒子の占め る体積を表すが，ビーム力学では運動が三次元空間に各々独立 であるとして，三つの二次元の位相空間での面積を用いる．慣 習として，エミッタンスと言えばビームの進行方向にたいして 横向きの運動方向エミッタンスを意味することが多いので, 本 文でもそれにならうことにした。進行方向のエミッタンスはエ ネルギー広がり, バンチ長として表記する. 
極を熱陰極（Thermionic Cathode）という. 代表的な物質 はタングステン, $\mathrm{BaO}, \mathrm{LaB}_{6}, \mathrm{CeB}_{6}$ などである. 電子ビーム は電子の熱運動によるエミッタンス $\varepsilon_{\mathrm{th}}$ を持ち, 金属の場 合, それは温度 $\mathrm{T}$ と rms ビーム径 $\sigma$ により次式で表される.

$$
\varepsilon_{\mathrm{th}}=\sigma \sqrt{\frac{k T}{m c^{2}}}
$$

ここで $m c^{2}$ は電子の静止質量エネルギーである. 熱院極 からの放出電流は仕事関数と温度から決定されるが，エミッ タンスは仕事関数には依存しないことがわかる，ここで例と して温度を $1500 \mathrm{~K}$, ビーム径を $1 \mathrm{~mm}$ とすると, 発生する ビームのエミッタンスは打よそ $0.5 \pi \mathrm{mm} . \mathrm{mrad}$ となる ${ }^{22}$.

光電効果を利用した電子発生デバイスを光電陰極（Photocathode）という. 入射光子数と発生電子数の比を量子効率 として定義して, 光電陰極の性能を表す指標として用いる. 典型的な光電陰極物質としては $\mathrm{Cu}, \mathrm{Mg}$ 等の金属, $\mathrm{Cs}_{2} \mathrm{Te}$ や GaAs などの半導体が使用される. 金属カソードは量子効率 が0.1-0.001\%と低いが, 堅牢で, かつ応答速度が早いのが 特徵である. 金属の光電陰極からのビームのエミッタンスは,

$$
\varepsilon_{\mathrm{m}}=\sigma \sqrt{\frac{\hbar \omega-\phi}{3 m c^{2}}+\frac{k T}{m c^{2}}}
$$

と与えられる15)。ここでは熱による寄与を入れ込んでい $ろ^{\dagger 3}$. ルートの中の第一項目は光電効果に用いたレーザーの 寄与, 第二項が熱エネルギーによる寄与である. 大抵の場 合, 第一項が支配的である. 例として銅㓌極を固体レーザー の四倍波である $266 \mathrm{~nm}$ の光で励起することを考えよう. 余 唾のエネルギーは4 $4.67 \mathrm{eV}-4.30 \mathrm{eV}=0.37 \mathrm{eV}$ であるから，

この項の寄与のみによるエミッタンスは $1 \mathrm{~mm}$ 径を仮定して $0.49 \pi \mathrm{mm} . \mathrm{mrad}$ となり, 熱陰極とほぼ同等となる ${ }^{\dagger 4}$. 熱陰極 に比べて温度が低いので, 光電陰極は原理的に極小エミッタ ンスが可能であるが，それにはレーザー波長の仕事関数への 合わせ込みが必要であることがわかる。しかし他方でレー ザー波長が仕事関数に近くなればなるほど, 光電子発生の量 子効率は減少していくことが知られている.

Fowlerの式の二次までの項をとると, 光電子発生の量子

†2 加速器では運動量にかわり $\mathrm{x}^{\prime}=\mathrm{p}_{\mathrm{x}} / \mathrm{p}_{\mathrm{s}}$ (横方向運動量を進行方 向の運動量で割った無次元量）を用いて，(x, $x^{\prime} ）$ を位相空間 とする。これよりエミッタンスの単位は $\mathrm{m} . \mathrm{rad}$ や $\mathrm{mm} . \mathrm{mrad}$ な ぞとなるが，面積を求めるさいに必然的に出てくる $\pi$ を単位 に入れ込んで $\pi \mathrm{mm} . \mathrm{mrad}$ などと表されることが多い.また， この定義では加速により $\mathrm{p}_{\mathrm{s}}$ が増大するにしたがってエミッタ ンスが減少するので，異なるエネルギーのビームを比較するさ いに不都合を生じる。そのため $\left(\mathrm{x}, \mathrm{x}^{\prime}\right)$ 空間の面積にローレ ンツ因子の $\gamma \beta$ を掛け合わせてエネルギー依存性を打ち消す。 こうして求められたエミッタンスを規格化エミッタンスと呼 ぶ. 本稿ででてくるエミッタンスはすべて規格化エミッタンス である.

†3 式 (2) は, $\mathrm{T}=0$ という条件での光電子放出における電子エネ ルギーと, 熱的に電子が持つエネルギーを各々求め, それらの 和として得られたものである. 有限温度における分布関数の直 接の積分を解析的に求めるのは困難である.

†4 陰極表面に高い電場が存在すると, Schottky 効果により仕事 関数が実質的に減少することが知られている. その効果を含め ると, 実際の RF 電子銃中に抢けるエミッタンスはより大きく なる.
効率の波長依存性は

$$
\eta \propto \frac{\pi^{2}}{6}+\frac{1}{2}\left(\frac{\hbar \omega-\phi}{k T}\right)^{2}
$$

と表され16)，レーザー波長の仕事関数への合わせこみによ り減少することがわかる゙5.すなわちエミッタンスの低下と 引き換えに必要なレーザーパワーが増大するのである．C． P. Hauri 等 ${ }^{17)}$ は $\mathrm{Cu}$ などの金属陰極から生成されるビームを 計測し, 式(2)が示すように波長を仕事関数に合わせ込むこ とでビームのエミッタンスが低減することを明らかにした。 また仕事関数に近い波長でも有限の量子効率を維持してお り，このような条件が実用に耐えうる可能性を示した。

$\mathrm{Cs}_{2} \mathrm{Te}$ や $\mathrm{GaAs}$ などの半導体陰極は量子効率は一般的に 1-20\%程度と高いが，カソードの活性化から使用まで超高 真空を維持する必要がある. また, 運転可能時間や引出し可 能電荷量などが真空圧力に大きく影響され, 実用化の上で大 きな課題となっている 18,19$),+6$. 半導体陰極の場合は, バンド 構造を有するために, 励起された電子のエネルギーが有効質 量に影響される. Fig. 1 に NEA-GaAs 光電陰極からの電子 放出の様子を模式的に示す. 価電子帯 (Valence Band) か らレーザーなどの光によって伝導帯に励起された電子は拡散 により表面へと到達する. 電子のエネルギーが真空準位より も高ければ電子として放出される. EA (Electron Affinity) とは伝導帯の底と真空準位との差で, Fig. 1 において $\chi$ と示 されている. NEA-GaAsではこのEAが負の值, NEA (Negative Electron Affinity) となっていることが知られて いる20). NEA とはすなわち真空準位が価電子帯よりも低い 特殊な表面状態のことである. 価電子帯と伝導帯の間にエネ

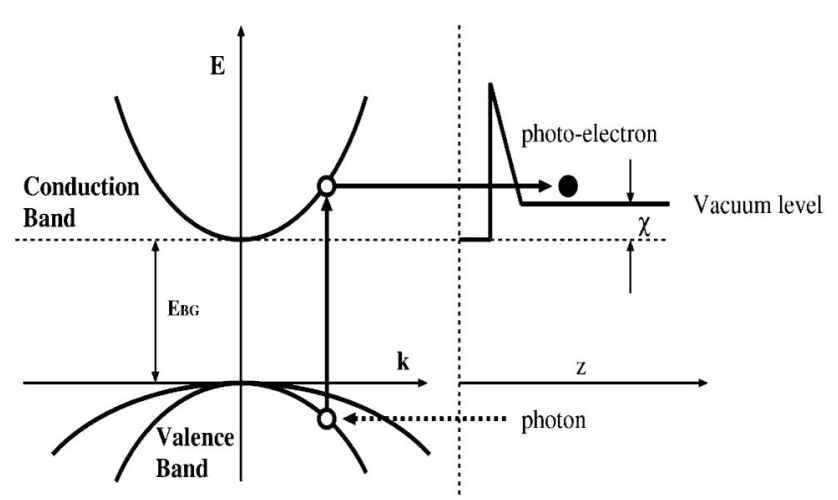

Fig. 1 Photo-emission from NEA-GaAs is schematically shown. Left part shows a band structure of a direct transitiontype semiconductor. Electrons excited to the conduction band move to its surface by diffusion. Right part shows the surface potential and $\chi$ is defined as EA. If the electron energy is above the vacuum level, the electron can be emitted as the photo-electron.

${ }^{\dagger 5}$ 温度 $\mathrm{T}=0$ と仮定すると $\eta \propto(\hbar \omega-\phi)^{2}$ となる.これは近似式 であり, 光のエネルギーが仕事関数に近い場合ずれが大きくな る. 有限の温度であれば必ずフェルミ準位より上に熱的に励起 された電子が存在するので, 量子効率はレーザーを仕事関数へ 近づけてもゼロにならない.

${ }^{\dagger 6}$ 真空圧力にして $1 \mathrm{E}-10 \mathrm{~Pa}$ 台を電子銃内で安定して実現するこ とが必要だと認識されている. 
ルギーバンドギャップ $E_{\mathrm{BG}}$ をもつ $\mathrm{GaAs}$ などの直接遷移型 の半導体で, 発生する電子のエミッタンスを求めると

$$
\varepsilon_{\mathrm{SC}}=\sigma \sqrt{\frac{2\left(\hbar \omega-E_{\mathrm{BG}}\right)}{3 m c^{2}} \frac{\mu}{m_{\mathrm{c}}}+\frac{k T}{m c^{2}}}
$$

となる ${ }^{21), \uparrow 7 . こ こ て ゙ ~} m_{\mathrm{c}}$ は伝導帯での有効質量, $\mu$ は光遷移

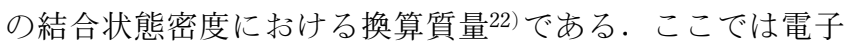
親和性 $\chi$ をゼロと置いている．この式から半導体陰極の場 合でも，エミッタンスを抑制するためには光の波長を $E_{\mathrm{BG}}$ に合わせ込む必要があることがわかる。 Pastuszka ら ${ }^{23)}$ NEA-GaAs 陰極からのビームについてエミッタンスを決め る横方向エネギーを計測した。その結果，レーザー波長が $E_{\mathrm{BG}}$ に相当するエネルギーで，横方向のエネルギーが熱エネ ルギーとほぼ等しくなることが示されている.

今までビーム径は独立に決まるパラメーターとして考えて きたが，実際には取り出せる電荷量は空間電荷効果により制 限される．Eをカソード面上に拈ける加速電場とすると, 電 荷量 $Q$ を取り出すのに必要なビーム径は

$$
\sigma=\frac{R}{2}=\frac{1}{2} \sqrt{\frac{Q}{\pi \varepsilon_{0} E}}
$$

である.ここで $\varepsilon_{0}$ は真空の誘電率で, 径方向に均一なパン ケーキ状の電荷分布を仮定しており， $R$ はその半径である. 実際のビームの電荷分布はレーザーのプロファイル等により 変化するが，電荷と電場の依存性はおよそ式(5)で表され る.これより, 電荷量と表面電場からおのずと必要な径が決 まり，式(1)，(2)，(4)などととあわせて，原理的に可能な エミッタンスの最小值が決まる.

実際には，ビーム生成後も空間電荷効果によるエミッタン スの増大が生じる. 空間電荷効果のうち, 非線形な成分のみ が実質的にエミッタンス増大に寄与するので，非線形空間電 荷効果をいかに小さくするかがエミッタンス低減からは重要 である，空間電荷効果そのものは相対論効果により $1 / \gamma^{2}$ に スケールして減少するので，速やかに加速することが必要で ある：この点からも表面電場を大きくすることのメリットは 大きい。 また，空間電荷効果の非線形成分を小さくするには $\mathrm{KV}$ 分布や均一分布など電荷分布をより均一化することが効 果的である.シミュレーションによると年，電荷分布の均 一化等により，この理想的なエミッタンス值に近い值が得ら れることが示されている。 また Bazarovらは原理的に可能 なエミッタンスの定式化を試み，例として $8.2 \mathrm{MV} / \mathrm{m}$ の表面 電場, $1 \mathrm{nC}$ のバンチ電荷でおよそ0.7 $\pi \mathrm{mm} . \mathrm{mrad}$ という值を 示している25).

以上から，低エミッタンス生成には次のことが重要なこと がわかる．まず発生するビームの横方向エネルギー（等価温 度としばしば言われる）を低減すること，これにはカソード の低温化，レーザーの仕事関数等への合わせこみが必要とな る。また，表面電場を大きくすることは，ビームスポット径 の矮小化と非線形空間電荷の低減を通じて，低エミッタンス

† ここでも式 (2) と同様にレーザーにより発生するエネルギーと 熱エネルギーをそれぞれ別に求め, 最後に和を求めている.
ビーム生成に効果的である。

\section{3. 低エミッタンス電子銃の動向}

$\mathrm{RF}$ 電子銃の典型的な表面電場は $40 \mathrm{MV} / \mathrm{m}$ から $120 \mathrm{MV} /$ $\mathrm{m}$ 程度である. 一方, $\mathrm{DC}$ 電子銃のそれは数 $\mathrm{MV} / \mathrm{m}$ から 10 $\mathrm{MV} / \mathrm{m}$ 足らずであり， RF 電子銃に比べて一桁程度低い值に なっている．この点からは $\mathrm{RF}$ 電子銃が低エミッタンス電子 発生に有利であると言える．特に大きなバンチ電荷を必要と する場合には，RF 電子銃が有利である。しかし一方で， $\mathrm{RF}$ 電子銃は共振構造という条件があるために設計自由度が 低く，低い真空圧力を要求する NEA-GaAs 陰極等の使用は 困難である ${ }^{\dagger 8} . \mathrm{DC}$ 型電子銃はバンチあたりの電荷量が比較 的低い場合や，偏極電子生成など NEA-GaAs 陰極が必要な 場合に用いられている。 また，パルス構造も電子銃を決定す るうえで重要な因子である. 一般的に高勾配で RF 電子銃を 連続運転することは，空洞内壁で消費されるジュール損失が 莫大となることから困難である. ERL (Energy Recovery Linac）など連続ビーム生成が要求される場合，連続運転が 可能な DC 電子銃が用いられる.

以下， $\mathrm{RF}$ 電子銃， $\mathrm{DC}$ 電子銃という順番で研究の動向を 紹介する，また，最後に唐突ではあるが，レーザー加速につ いての私見も述べさせていただく．レーザー加速は研究開発 が盛んに行われている一方で, 加速器技術としてはまだ未成 熟というのが一般的な見方である。しかし，レーザー加速の 特性を考えると, 将来的には究極の高輝度電子源として非常 に高いポテンシャルを有していると思われる。

\section{$3.1 \mathrm{RF}$ 電子銃}

$\mathrm{RF}$ 電子銃は $\mathrm{RF}$ 空洞内で直接電子ビームを生成し，その まま数 $\mathrm{MeV}$ 程度まで加速するデバイスである. J. S. Fraser ら ${ }^{26)}$ により FELのための電子入射器として提案された.

$\mathrm{RF}$ 電子銃には陰極に熱陰極を用いるタイプと光電陰極を 用いるタイプがある. 熱陰極タイプではビームは連続的に発 生するため， RF 空洞の位相に応じて広いエネルギー広がり をもつビームが出力される，そのビームの一部をアルファ型 磁石などで切り出して使用する.しかしどうしてもビームの 一部はカソードに逆流してカソードの温度上昇を招くために 安定した運転が困難であるという欠点がある．光電陰極を用 いたタイプはレーザーの時間構造（パルス幅）により発生す るビーム構造を制御できる。そのため熱院極で生じるような 逆流による不安定性がないのが長所である. RF 電子銃は光 電陰極型を中心に開発がすすめられ，現在ではSLAC (Stanford Linear Accelerator Center), BNL (Brookhaven National Laboratory), UCLA で共同開発された BNL 型27,28) と呼ばれるものが広く使用されている．Fig. 2 に BNL 型の $\mathrm{RF}$ 電子銃の電場プロファイルを断面でしめす．図の下端が 中心軸に相当し, 左端で発生した電子ビームは右に向かって 加速される．このように BNL 型は二つのセルからなる共振

\footnotetext{
†8 極低真空圧力を実現することが困難なことに加えて，RF 電子 銃内部では高い表面電場に起因する電界放出電子（ビームと区 別して暗電流と呼ぶ）の存在が大きな障害となる．暗電流の多 くは電場の逆転によりカソードに逆流衝突し，NEAカソード 表面を破壊することが知られている.
} 


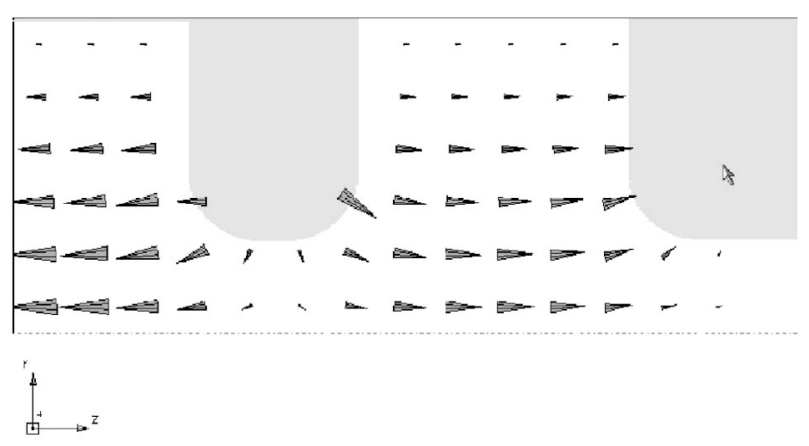

Fig. 2 The half cross section of BNL type RF gun with electric field profile. The left end corresponds to the end plate. Electrons generated by the cathode placed at the center of the end plate, is accelerated to right direction.

構造をとって抢り，位相差 $\pi$ の定在波型空洞である. 共振 周波数は2856 MHz のS-band であり, 光電院極での表面電 場は $90 \mathrm{MV} / \mathrm{m}$ から $120 \mathrm{MV} / \mathrm{m}$ 程度が実現されている。

SLACのX線FELであるLCLS (Linac Coherent Light Source) の入射器 ${ }^{29)} に も \mathrm{BNL}$ 型の RF 電子銃が使用されて おり，カソードには空洞の構造材である銅をそのまま使用し ている. $\mathrm{Cu}$ の量子効率は $0.01 \%$ から $0.001 \%$ 程度と低いが, 構造が単純である点が利点である. また, 比較的低い繰り返 しであれば数 $\mathrm{nC}$ 程度のバンチを生成することは現在のレー ザー技術からすれば容易である. BNLでは $\mathrm{Cu}$ より量子効 率が一桁から二桁高い $\mathrm{Mg}$ をカソードに用いている30). 銅 の母材にディスク状の $\mathrm{Mg}$ を熱的にかしめて固定してい る.製作に手間がかかること， $\mathrm{Cu}$ と $\mathrm{Mg}$ の境界で放電を生 じる可能性があることが欠点である. KEK では BNL 型 RF 電子銃でマルチバンチビームを生成するため, $1.0 \%$ 程度の 量子効率が得られる $\mathrm{Cs}_{2} \mathrm{Te}$ カソード31)を使用している． $\mathrm{Cs}_{2}$ Te カソードは CERN（欧州原子核研究所）により開発され たカソード材料で, 真空中で Cs と Te を蒸着させて生成す る. また, 生成後に大気にさらすと使用不可能となるため に, カソード生成用の真空蒸着槽に加えて電子銃まで真空中 を移送する機構が必要となる。そのため装置が大がかりとな るが, $\mathrm{RF}$ 電子銃の内部で安定的に $1 \%$ 程度の量子効率を維 持できる唯一のカソード材料である. KEK ではリニアコラ イダーのために開発された銅の超精密加工技術32)を用いて 電子銃空洞を加工し, 従来型の加工に比べて大幅に低い 80 $\mu \mathrm{A}$ 程度（2.5 $\mu \mathrm{s}$ パルス内平均）の暗電流を実現している. カソード表面に抬いて $115 \mathrm{MV} / \mathrm{m}$ という高い電場で定常的 に運転されて抢り，バンチ電荷 $1.6 \mathrm{nC} て ゙ 1.5 \pi \mathrm{mm} . \mathrm{mrad}$ とい う低いエミッタンスを実現している33). Fig. 3 に仮組途中 の $\mathrm{RF}$ 電子銃の内部を示す. 加工はダイヤモンドバイトによ る超精密旋盤でおこない, 加工後は研磨などの処理をおこな っていないが, 鏡面様の滑らかな表面が得られている. 大阪 大学では, 電子回折実験やパルスラジオリシスなどの RF 電 子銃の先進的利用に焦点をしぼり研究をすすめている. 使用 しているのは銅カソードの BNL 型で, $0.6 \mathrm{nC}$ のバンチ電荷 で $1.91 \pm 0.28 \pi \mathrm{mm} . \mathrm{mrad}$ というエミッタンスを実現してい る34). DESY は XFEL ${ }^{10)}$ 抢よび電子陽電子リニアコライダ 一35)のための超伝導加速技術の開発を目的として,

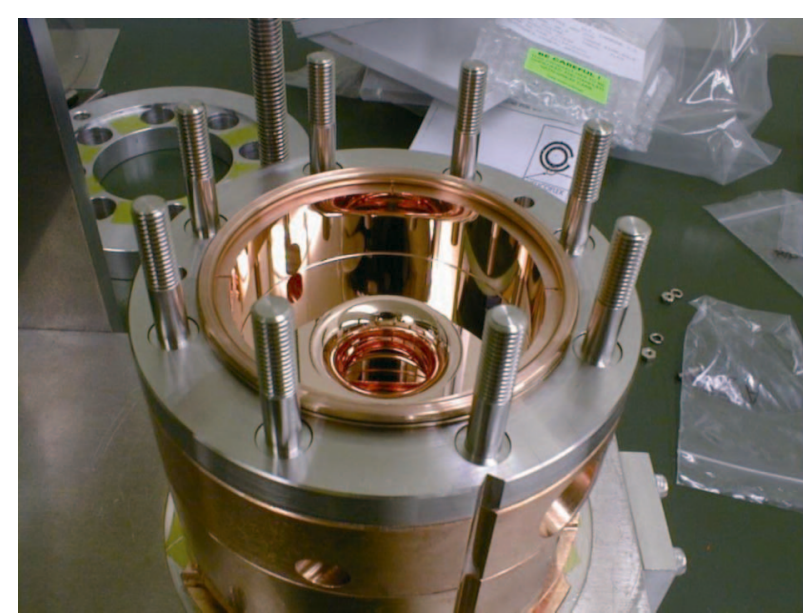

Fig. 3 Picture during the test assembly of RF Gun after the cavity machining by the super-fine lathe with diamond bite. Center hole corresponds to the iris between two cells. The cavity is not current gun at KEK-ATF, but the machining is identical.

FLASH/TTF 10$)$ という試験加速器を建設した. 超伝導での 効率的な加速を行うためには, パルスの繰り返しは低く, 一 つのパルスはなるべく長く，そして一つのパルスあたりにな るべく多くのバンチを詰め込んで運転することが好ましい.

FLASH/TTF では最大で执よそ $1 \mathrm{~ms}$ という長大パルス加 速が行われている. そのような長いマクロパルス構造を発生 できる電子銃として, $1300 \mathrm{MHz}$ の共振周波数を持つ常伝導 の RF 電子銃が開発された ${ }^{36,37)}$. DESY-PITZ (Photo-Injector Test facility at DESY-Zeuthen)において FLASH/ $\mathrm{TTF}-\mathrm{RF}$ 電子銃の運転試験が行われ， $45 \mathrm{MV} / \mathrm{m}$ というデ ザイン值に近い $42 \mathrm{MV} / \mathrm{m}$ というピーク加速電場を実現して いる. また $1.0 \mathrm{nC}$ のバンチ電荷量で， $1.5-2.0 \pi \mathrm{mm} . \mathrm{mrad}$ と いうエミッタンスを生成している38).

$\mathrm{RF}$ 電子銃は高い加速勾配を実現できるが，長いパルス生 成や連続ビーム生成にはジュール熱の発生が問題となる。一 定の $\mathrm{RF}$ パワーPを投入したときに発生する加速電場 $E$ は シャントインピーダンス $R$ を用いて

$$
E=\sqrt{P R}
$$

と表される。長大パルス運転における Figure of merit とし て加速電場を空洞壁の単位面積当たりの消費電力で規格化し たもの

$$
F o M=\frac{E}{P / S}
$$

が考えられる.Sは空洞内壁の面積である.シャントイン ピーダンスは高周波の周波数に対して $\sqrt{\omega} の$ 依存性を持って いる. 他方, 空洞内壁の面積は $1 / \omega^{2}$ の依存性であるので, これらを代入すると

$$
F_{O} M \sim \frac{1}{E \omega^{1.5}}
$$

となり，より周波数が低いほうが望ましいことがわかる. 
$\mathrm{BNL}$ 型 $\mathrm{RF}$ 電子銃は短パルス（数 $\mu$ 秒程度）で, 2856 $\mathrm{MHz}$ という高い周波数で $100 \mathrm{MV} / \mathrm{m}$ と高い加速勾配を実現 しているのに対して, Boeingによる $433 \mathrm{MHz}$ の RF 電子銃 は duty factor $25 \%$ という連続運転に近い状態で $32 \mathrm{~mA}$ (パ ルス内平均だと $132 \mathrm{~mA}$ ) という大電流を発生させた実績を 有している39). FLASH/TTF の $1300 \mathrm{MHz}$ 電子銃はその中 間に位置すると言っていいだろう.しかし常伝導 RF 電子銃 で連続運転を目指寸研究開発は, その後活発に行われている とは言えない†9.

空洞壁での電力損失を抑えるということを考えると，すぐ に思いつくのは超伝導で RF 電子銃をつくることである. 超 伝導 $\mathrm{RF}$ 電子銃の研究は1988年というかなり早い段階から 試みられてきだ1). 超伝導空洞を加速器に本格的に導入し たのは KEKのTRISTAN 加速器3)であるが, その後超伝導 加速技術は急速に進歩を見せ, 現在では大型の超伝導線形加 速器（DESYのXFEL/FLASH ${ }^{10)}$ はその代表）が建設され ている．このように超伝導加速技術自体は大きく進展してい る一方で, 超伝導RF電子銃の開発には長い間進展が見られ なかった. 超伝導加速と比較して, 超伝導 $\mathrm{RF}$ 電子銃が抱え る課題は大きくわけて二つある. 二つとも光陰極を空洞内に 配置するということに由来しており, 超伝導 $\mathrm{RF}$ 電子銃固有 の技術的課題である. 一つめの課題は, 光陰極は超伝導物質 ではないため, 大量の熱が発生することである。この熱が原 因となり，クエンチを引き起こして超伝導状態が破れてしま うのである. この問題の解決のために, チョーク構造が考案 され，陰極と超伝導空洞を直接接触させず，熱伝導を低く抑 えるという技術が開発された.二つめは, 光電陰極という 「異物」を空洞内に持ち込むことで, 空洞内が污染され, 電 界放出などにより超伝導空洞内壁そのものの発熱が増えてし まう問題である。これらの困難は抱えつつも, Forshungszentrum Dresden Rossendorf のグループは2002年に世界 で初めて超伝導 RF 電子銃によるビーム生成に成功した ${ }^{42)}$. この電子銃は光陰極のマウント部にチョーク構造を導入し, $\mathrm{Cs}_{2} \mathrm{Te}$ カソードで平均電流 $18 \mu \mathrm{A}$, バンチ電荷 $80 \mathrm{pC}$ で $3 \pm 1$ $\pi \mathrm{mm} . \mathrm{mrad}$ というエミッタンスを実現している.この成功 に触発され, 現在では複数の研究機関が超伝導 $\mathrm{RF}$ 電子銃の 開発研究に取り組んでいる43).

\section{$3.2 \mathrm{DC}$ 電子銃}

$\mathrm{DC}$ 電子銃は連続運転が可能なこと, 設計自由度が高いこ と, などが長所である. 他方, 加速勾配が RF 電子銃に比べ て劣るため, 低エミッタンスビーム生成には, バンチ電荷を 低く抑える, ピークカレントを抑制する, などの工夫が必要 である。

設計自由度の高さは, DC 型電子銃での NEA-GaAs 陰極 の使用を可能にする. 西谷ら ${ }^{44)}$ は GaAs 院極に量子井戸によ る超格子構造をつくることで伝導帯にミニバンドを形成し, 物質側の構造を利用した低エミッタンス化を提案した．この 物質を陰極に用いることで，原理的に発生するビームのエネ

†9 LANL ( Los Alamos National Laboratory) や LBNL (Lawrence Berkeley National Laboratory) などで開発が行わ れている．興味のある方は参考文献40)等を参照していただきた い.

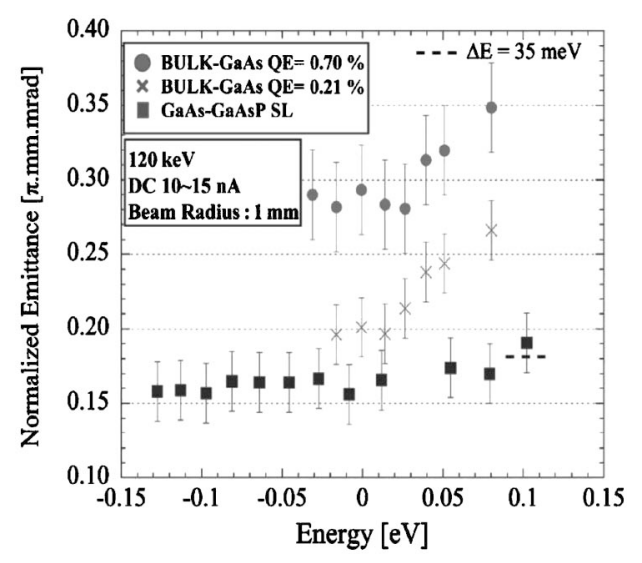

Fig. 4 Beam emittance from NEA-GaAs photo-cathode as a function of residual energy of photo-excitation, i.e. laser photon energy minus $E_{\mathrm{BG}}$. Emittance of Super-lattice cathode is much suppressed comparing to that of Bulk-GaAs. Reprinted with permission from N. Yamamoto et al., Journal of Applied Physics, 102, 024904, (2007) ${ }^{45)}$. Copyright 2011, American Institute of Physics.

ルギー広がりがこのミニバンド幅以下に抑制されることとな るため, 極めて小さいエミッタンスのビームを発生できるこ とが期待された。続いて山本ら ${ }^{45)}$ は，ミニバンド幅が 35 $\mathrm{meV}$ の超格子カソードからのビームエミッタンスを計測 し, エミッタンスが $1 \mathrm{~mm}$ ビーム径で $0.16-0.18 \pi . \mathrm{mm} . \mathrm{mrad}$ という值を計測し, 超格子カソードによる優位性を実証した.

Fig. 4 にとの結果を示す。横軸はレーザーとバンドギャッ プエネルギー $E_{\mathrm{BG}}$ との差である.この計測においては超格 子構造のない通常の p 型 GaAs（Bulk-GaAs）㓌極と超格子 GaAs 陰極とを比較し，レーザーの波長に対するエミッタン スの依存性も計測している. Fig. 4 で示されている通り, Bulk-GaAs 陰極からのエミッタンスがエネルギーとともに 増大するのにたいして, 超格子 $\mathrm{GaAs}$ 陰極はエミッタンス増 大が大幅に抑制されていることがわかる. 超格子 GaAs 陰極 では式(4)から予想されるようなエミッタンス増大は見られ ず，超格子構造による閉じ込め効果が実証されたといえる.

各地で計画されている ERL (Energy Recovery Linac)の 電子銃は低バンチ電荷, 高繰り返しで, 大電流の低エミッタ ンスビーム実現を目指すものである，ERLでは電子銃から 連続して $100 \mathrm{~mA}$ 程度の大電流電子ビームを生成する．この ビームを入射加速器でまず $10 \mathrm{MeV}$ 程度まで加速し, さらに 主加速器で目的となるエネルギー（数 $\mathrm{GeV}$ 程度）まで加速 する.この加速されたビームをアンジュレーターなどの発光 用の電磁石を通過させ, 放射光を発生させる.このビームは 加速されたばかりのフレッシュなビームであるから, 量子励 起の影響などを大幅に抑制できるため, 入射電子ビームの性 能を極めて高くできれば，究極の高輝度光源が実現される. $5 \mathrm{GeV}$ クラスの $\mathrm{ERL}$ 加速器を考えると, 電子銃で 0.1 $\pi \mathrm{mm} . \mathrm{mrad}$ 程度のエミッタンスを実現できれば, $1 \AA$ の波長 に拈いて回折限界光が実現可能である. 発光に使用された ビームはもう一度主加速器に送り込まれるが, この時ビーム は減速位相に乗せられる. ビームは主加速器の出口では入射 エネルギーと等しい $10 \mathrm{MeV}$ 程度まで減速され，それから 


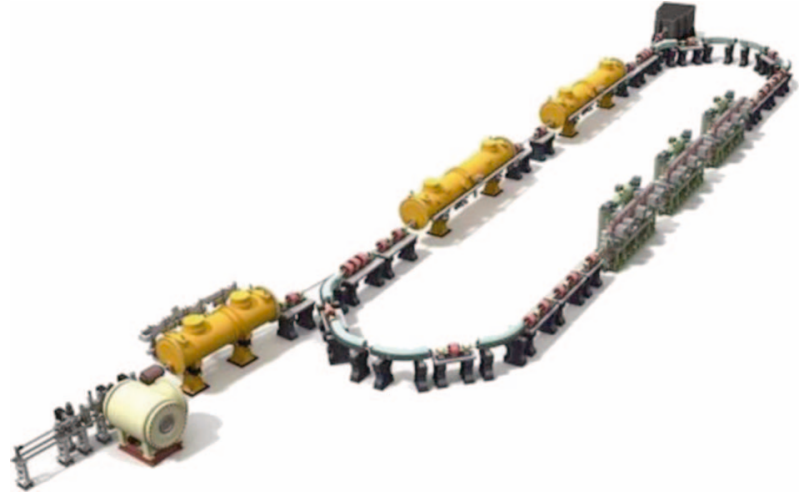

Fig. 5 3D graphical view of CERL (Compact ERL) as demonstrator. Left down part corresponds to the electron gun. The generated electron beam is accelerated by the injector cavity and boosted up to $200 \mathrm{MeV}$ by the main linac. The electron beam is injected to the main linac again, but on the deceleration phase.

ビームダンプに送られる．減速するときに失われたエネル ギーは空洞内の電磁場として蓄えられ, 次のビーム加速に使 用される. 実際には空洞内に同時に加速ビームと減速ビーム が同居して, 電磁場を媒介して減速ビームから加速ビームへ とエネルギーが移動していることになる．このエネルギー回 収機構により毎回フレッシュな電子ビームを使用するという 贅沢な加速器が可能となる.

このように ERL では量子励起が大幅に抑制されるため, FEL と並ぶ究極の放射光源として注目されている. ERL は 米国ジェファーソン研究所 (JLAB) / Cornell 大学 ${ }^{46)}$, 英国 Daresubury 研究所, 日本の $\mathrm{KEK} / \mathrm{JAEA}^{47}$ 等が数 $\mathrm{GeV}$ クラ スの計画を進めている. Fig. 5 に KEK/JAEA が中心とな りすすめている ERL 実証機の模式図を示す. 図の左下が電 子銃である。

ERL はこのように魅力的な放射光源である一方, 電子銃 に対する要求は従来型の加速器に比して極めて厳しい. 第三 世代放射光源では電子ビームは周回軌道をまわり続けるた め, 立ち上げ時などを除けば, 残留ガスとの散乱などの原因 で減少していくビーム電流を補うだけでよかった。一方, ERL では電子銃で発生させるビーム電流と発光に使用され るビーム電流は等しいので, 電子銃で $100 \mathrm{~mA}$ クラスの電流 を実現させなければならない。 また ERL としての性能を発

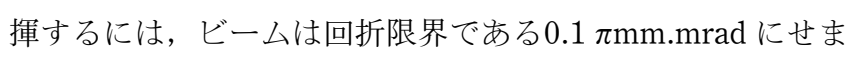
る低エミッタンスであることが要求される.すでに説明した ように低エミッタンスと大電流はトレードオフの関係にあ り, 簡単には実現しないが，その候補がすでに何回か触れた $\mathrm{NEA}-\mathrm{GaAs}$ 光電陰極である. 多くの ERL 計画が NEA$\mathrm{GaAs}$ 光電陰極を使用した DC 型の電子銃を開発目標に掲げ ている. JLAB は500 kVのDC 電子銃を目標としており, 現在までに $320 \mathrm{kV}$, 電場にして $3.9 \mathrm{MV} / \mathrm{m}$ を実現している. $135 \mathrm{pC}$ までのバンチ電荷を $37 \mathrm{MHz}$ 程度の繰り返しで発生 しており, ビーム電流は $5 \mathrm{~mA}$ 程度である. スポット径は 6 $\mathrm{mm}$ で, エミッタンス $15 \pi \mathrm{mm} \cdot \operatorname{mrad}$ が得られている ${ }^{48)}$. JAEA では DC $250 \mathrm{kV}$ 電子銃により，0.15 mm という極小

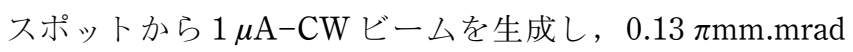

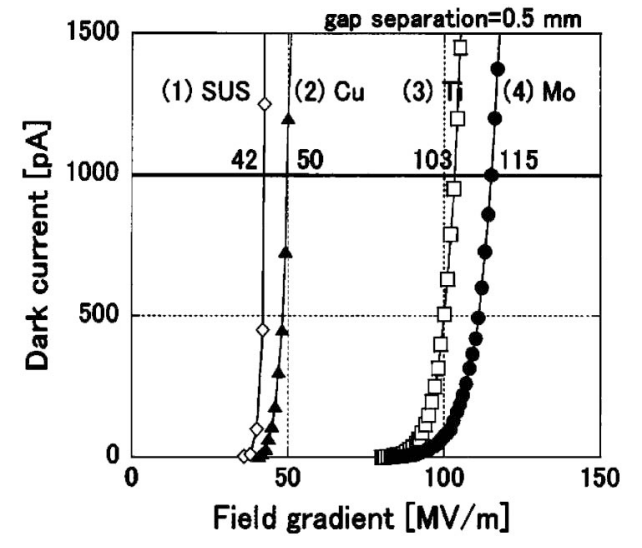

Fig. 6 Dark current through field emission process from various materials are shown as a function of surface field. Ti and Mo have good performance comparing to $\mathrm{Cu}$ and SUS from the high field electrode point of view. Reprited with permission from ref. ${ }^{50)}$. Copyright 2011, Elsevier B. V.

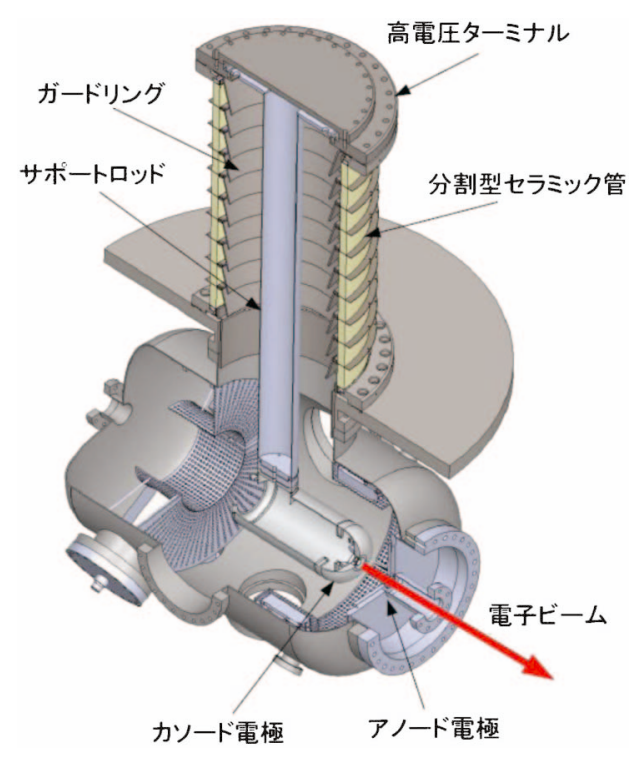

Fig. 7 Schematical view of $500 \mathrm{kV}$ electron gun developed by a group led by JAEA and KEK. It demonstrates a stable operation at $500 \mathrm{kV}$ in 2010.

という極小エミッタンスを実現している ${ }^{49)}$.

DC 型電子銃で低エミッタンスかつ大電流のビームを生成 するためには，高い表面電場と加速電圧を実現することが必 要である. DC 電子銃の高電圧化の障壁となるのは最終的に は絶縁破壊などの破壊的な放電現象であるが，その前段階と しての電界放出による電極からの暗電流を低減する必要があ る. 暗電流は NEA-GaAs 陰極のもう一つの課題である寿命 問題とも関連しており, ERLの実現にとってその低減は重 要な項目である. 古田 $5^{50)}$ は清浄な金属表面からの暗電流 を調べ，Mo と Ti が暗電流低減に有利であるとの結論を得 た．Fig. 6 にその結果をしめす．KEK と JAEAを中心とす るグループはこの知見を活かし， ERL 実証機47)のための500 $\mathrm{kV}$ 電子銃開発をすすめ, 2010年には $500 \mathrm{kV}$ の安定印可に 世界で初めて成功した ${ }^{51)}$. Fig. 7 にその電子銃の模式図を 示す.この電子銃には電極材料の知見に加えて, 放電時のダ 
メージがセラミックの特定部分に集中することを防ぐための 分割電極構造, 内導体から発生した暗電流由来の電子が直接 セラミックに当たらないように遮蔽するためのガードリン グ，などの工夫が凝らされている。この電圧では $7.7 \mathrm{pC}$ 程 度のバンチ電荷で $0.1 \pi \mathrm{mm} . \mathrm{mrad}$ という超低エミッタンス ビームが期待され, 現在はビーム試験に向けて準備が進めら れている.

$\mathrm{DC}$ 電子銃の高電圧化と低エミッタンス電子ビーム生成に 独自の切り口から取り組んで成功しているのが理研播磨の XFELの入射器52)である。この電子銃は電圧をパルスで印 可し通常は困難な $500 \mathrm{kV}$ という加速電圧を作り出してい る.カソードには $\mathrm{CeB}_{6}$ 熱カソードを使用し，抢よそ $3 \mu \mathrm{s}$ という長いバンチとして生成し, 圧縮してから加速を行うと いう，伝統的な入射器の構成をとっている．ピーク電流を抑 制することで空間電荷効果によるエミッタンス増大を抑制す るというアイデアである。測定されたエミッタンスは $1 \mathrm{~A}$ のピーク電流で $1.1 \pi \mathrm{mm} . \mathrm{mrad}$ である52). 理研播磨 XFEL の試験加速器である SCSSに拈いて, FELのSASE 発振が 観測されたのはご存じの通りである53).この低エミッタン スビームを壊すことなく，加速できていることのなによりの 証である.

\section{3 レーザー加速}

レーザー加速はレーザーがプラズマ中に引き起こす航跡場 (Wakefield) により, 通常の RF 加速器に比べて極めて高い $\mathrm{GV} / \mathrm{m}$ 以上の加速場を生じさせ, プラズマ中の電子を加速 する. 田島とDawson ${ }^{54)} に よ り 1979$ 年に提案され，2000年 代に入り擬単色ビーム加速に成功する例が多く報告されてい る55-57). レーザー加速では短パルスレーザーを微小スポッ トに収束させ，加速を行う。これは見方を変えればプラズマ を陰極とした，特殊なレーザー場による光電効果と考えられ る．電子ビームによる低エミッタンスの実現には，低い温 度, 微小なスポット径, そして高い加速電場が必要である が，このうちレーザープラズマ加速は微小スポット径と高い 加速電場という条件を満たしている．とれも従来の電子銃に 比して桁違いの值である.このことから筆者はレーザー加速 は究極の高輝度電子源としての可能性を秘めていると考えて いる. 現在のレーザー加速の課題は安定性（再現性）と繰り 返し加速の実現であるが，このうち安定性さえ実現できれば レーザー加速は高輝度電子源として，世間で考えられている よりも早く実用化されうるのではないか， と筆者は期待して いる.

\section{4. まとめ}

加速器における低エミッタンス電子銃の最近の動向につい てまとめた．電子銃に拈いて低エミッタンス化が意識される ようになったのはそんなに昔のことではない，そこで前半に おいて低エミッタンスビーム生成のために考慮すべき事項 を，自らの頭の整理も兼ねてまとめた．後半では RF 電子銃 と DC 電子銃に分けて最近の動向をレビューした．短パルス 型の RF 電子銃は技術的にほぼ完成しつつあり，中心課題は この特性を活かした利用に移っているようだ. それに対して 連続運転を含む長パルス型の $\mathrm{RF}$ 電子銃は安定した運転のた
めの課題が多いように思う。また超伝導 RF 電子銃はまだ研 究開発の黎明期であり, 今後の発展が期待される. DC 型電 子銃は JLAB の電子銃に代表されるように，100 kV クラス では安定した運転が実現されており，低いバンチ電荷では極 低エミッタンスも実現されている. 課題はバンチ電荷の高い 高輝度運転でエミッタンス増大を抑制する高電圧での運転の 実現である. Cornell と JAEA/KEK グループで500 kV 運転 を目指した競争が続いてるが，筆者も共同研究者の一人であ る JAEA/KEK グループが500 kVの安定印可を実現したこ とは大きな成果である。また理研播磨 XFEL/SCSS が独自 のアプローチで SASE 発振を実現したことは特筆に值する.

最後にレーザー加速への高輝度電子源としての可能性への 期待も含めて，筆者なりの考えを述べてみた.

以上のようにさまざまな研究を紹介したが，もちろんすべ ての研究を網羅しているわけではない。しかし研究の動向を 把握するうえで不可欠なものは含めたつもりである. 加速器 に打ける電子銃は本体から比べると小さな存在であるが，加 速器全体の性能を左右するといっても過言ではない，本稿が 加速器に抢ける電子銃の重要性を再考するきっかけとなり, なんらかの研究の発展に寄与できれば幸いである.

\section{〔文献〕}

1) J. Pierce: J. Appl. Phys., 10 (1939) 548.

2) LEP design report, CERN-LEP-84-01 (1984).

3) TRISTAN design report, KEK (1977).

4) KEKB design report, KEK report95-7 (1995).

5) http://pfwww.kek.jp

6) JAERI-RIKEN Spring8 project team, Conceptual Design Report (1991).

7) H. Wiedemann: Particle Accelerator Physics I (Springer, 1993).

8) L. R. Elias, W. M. Fairbank, J. M. J. Madey, H. A. Schwettman and T. I. Smith: Phys. Rev. Lett., 36 (1976) 717.

9) T. Shintake, H. Tanaka, T. Hara, T. Tanaka, K. Togawa, M. Yabashi, Y. Otake, Y. Asano, T. Fukui, T. Hasegawa, A. Higashiya, N. Hosoda, T. Inagaki, S. Inoue, Y. Kim, M. Kitamura, N. Kumagai, H. Maesaka, S. Matsui, M. Nagasono, T. Ohshima, T. Sakurai, K. Tamasaku, Y. Tanaka, T. Tanikawa, T. Togashi, S. Wu, H. Kitamura, T. Ishikawa, T. Asaka, T. Bizen, S. Goto, T. Hirono, M.Ishii, H. Kimura, T. Kobayashi, T. Masuda, T. Matsushita, X. Maréchal, H. Ohashi, T. Ohata, K. Shirasawa, T. Takagi, S. Takahashi, M. Takeuchi, R. Tanaka, A Yamashita, K. Yanagida and C. Zhang: Phys. Rev. ST Accel. Beams, 12 (2009) 070701.

10) Conceptual Design Report, TESLA-FEL 95-03, DESY (1995).

11) LCLS conceptual design report, SLAC-R-593 (2002).

12) J. Urakawa: Nucl. Instr. \& Meth. A, 637 (2011) S47.

13) S. Schaefer, W. Liang, A. Zewail: Chem. Phys. Lett., 493 (2010) 11.

14) N. D. Browning, G. H. Campbell, J. E. Evans, T. B. LaGrange and B. W. Reed: ChemPhysChem, 11 (2010) 781.

15) D. Dowell and J. Schmerge: Phys. Rev. ST Accel. Beam, 12 (2009) 074201.

16) C. Crowell, T. Kao, C. Anderson and V. Rideout: Surf. Sci., 32 (1972) 591.

17) C. P. Hauri, R. Ganter, F. Primpec, A. Trisorio, C. Ruchert and H. Braun: Phys. Rev. Lett., 104 (2010) 234802.

18) J. Grames, R. Suleiman, P. A. Adderley, J. Clark, J. Hansknecht, D. Machie, M. Poelker and M. L.Stutzman: Phys. Rev. ST Accel. \& Beams, 14 (2011) 043501.

19) M. Kuriki, C. Shonaka, H. Iijima, D. Kubo, H. Okamoto, H. 
Higaki, K. Ito, M. Yamamoto, T. Konomi, S. Okumi, M. Kuwahara and T. Nakanishi: Nucl. Instr. \& Meth. A, 637 (2011) S87.

20) D.T Pierce and F. Meier: Phys. Rev. B, 13 (1976) 5484.

21) M. Kuriki: Lecture material, (Hiroshima Univ., 2010).

22) P. Yu and M. Cardona: Fundamentals of Semiconductors, (Springer, 2005).

23) S. Pastuszka, D. Kratzmann, D. Schwalm, A. Wolf and A. S. Terekhov: Appl. Phys. Lett., 71 (1997) 2967.

24) J. Limborg: Proc. of FEL Conf., (2005) 416.

25) I. Vazarov, B. Dunham and C. Sinclair: Phys. Rev. Lett., 102 (2009) 104801.

26) J. Fraser and R. Sheffield: Nucl. Instr. \& Meth. A, 250 (1986) 71.

27) D. T. Palmer, X. J. Wang, R. H. Miller, M. Babzien, I. Ben-Zvi, C. Pellegrini, J. Sheehan, J. Skaritka, H. Winick, M. Woodle and V. Yakimenko: Proc. of 1997 Particle Accel. Conf., (1998) 2687.

28) X. J. Wang and I. Ben-Zvi: Proc. of 1997 Particle Accel. Conf., (1998) 2793.

29) P. R. Bolton, J. E. Clendenin, D. H. Dowell, M. Ferrario, A. S. Fisher, S. M. Gierman, R. E. Kirby, P. Krejcik, C. G. Limborg, G. A. Mulhollan, D. Nguyen, D. T. Palmer, J. B. Rosenzweig, J. F. Schmerge, L. Serafini and X.-J. Wang: Nucl. Instr. \& Meth. A, 483 (2002) 296.

30) X. J. Wang, M. Babzien, R. Malone and Z. Wu: Proc. of Linac2002, (2002) 143.

31) P. Michelato: Nucl. Instr \& Meth. A, 393 (1997) 455.

32) T. Higo: Proc. of Linac2010, (2010) FR104.

33) N. Terunuma, A. Murata, M. Fukuda, K. Hirano, Y. Kamiya, T. Kii, M. Kuriki, R. Kuroda, H. Ohgaki, K. Sakaue, M. Takano, T. Takatomi, J. Urakawa, M. Washio, Y. Yamazaki and J. Yang: Nucl. Instr. \& Meth. A, 613 (2010) 1.

34) J. Yang, F. Sakai, Y. Okada, M. Yorozu, T. Yanagida and A. Endo: Nucl. Instr. \& Meth. A, 491 (2002) 15.

35) TESLA Technical Design Report (2000).

36) J. Baehr, I. Bohnet, J.-P. Carneiro, K. Floettmann, J. H. Han, M. v. Hartrott, M. Krasilnikov, O. Krebs, D. Lipka, F. Marhauser, V. Miltchev, A. Oppelt, B. Petrossyan, S. Schreiber and F. Stephan: TESLA Note 2003-33 (2003).

37) B. Dwersteg, K. Floettmann, J. Sekutowicz and Ch. Stolzenburg: Nucl. Instr. \& Meth. A, 393 (1997) 93.

38) K. Abrahamyan, J. Bähr, J. P. Carneiro, K. Flöttmann, J. H. Han, M. v. Hartrott, M. Krasilnikov, D. Lipka, V. Miltchev, A. Oppelt, B. Petrossyan, D. Pose, D. Richter, S. Schreiber, L. Staykov and F. Stephan: Nucl. Instr. \& Meth A, 558 (2006) 249.

39) D. H. Dowell, S .Z. Bethel and K. D. Friddell: Nucl. Instr. \& Meth. A, 356 (1995) 167.

40) S. S. Kurennoy, D. L. Schrage, R. L. Wood, L. M. Young, T. Schultheiss, V. Christina and J. Rathke: Nucl. Instr. \& Meth. A, 528 (2004) 392.

41) H. Chaloupka, H. Heinrichs, A. Michalke, H. Piel, C. K. Sinclair, F. Ebeling, T. Weiland, U. Klein and H. P. Vogel: Nucl. Instr. \& Meth. A, 285 (1989) 327.

42) D. Janssen, H. Büttig, P. Evtushenko, M. Freitag, F. Gabriel, B. Hartmann, U. Lehnert, P. Michel, K. Möller, T. Quast, B. Reppe, A. Schamlott, Ch. Schneider, R. Schurig, J. Teichert, S. Konstantinov, S. Kruchkov, A. Kudryavtsev, O. Myskin, V.
Petrov, A. Tribendis, V. Volkov, W. Sandner, I. Will, A. Matheisen, W. Moeller, M. Pekeler, P. v. Stein and Ch. Haberstroh: Nucl. Instr. \& Meth. A, 507 (2003) 314.

43) A. Arnold and J. Teichert: Phys. Rev. ST Accel. Beams, 14 (2011) 024801.

44) T. Nishitani, T. Nakanishi, M. Yamamoto, S. Okumi, F. Furuta, M. Miyamoto, M. Kuwahara, N. Yamamoto, K. Naniwa, O. Watanabe, Y. Takeda, H. Kobayakawa, Y. Takashima, H. Horinaka, T. Matsuyama, K. Togawa, T. Saka, M. Tawada, T. Omori, Y. Kurihara, M. Yoshioka, K. Kato and T. Baba: J. Appl. Phys., 97 (2005) 094907.

45) N. Yamamoto, M. Yamamoto, M. Kuwahara, R. Sakai, T. Morino, K. Tamagaki, A. Mano, A. Utsu, S. Okumi, T. Nakanishi, M. Kuriki, C. Bo, T. Ujihara and Y. Takeda: J. Appl. Phys., 102 (2007) 024904.

46) G. H. Hoffstaetter, B. Barstow, I. V. Bazarov, S. Belomestnykh, D. Bilderback, S. Gruner, M. Liepe, H. Padamsee, D. Sagan, V. Shemelin, C. Sinclair, R. Talman, M. Tigner, V. Veshcherevich, G. A. Krafft and L. Merminga: Proc. of 2003 Particle Accel. Conf., (2003) 192.

47) R. Hajima, N. Nakamura, S. Sakanaka and Y. Kobayashi: Design study of the compact ERL, KEK-Report 2007-7 (2007).

48) T. Siggins, C. Sinclair, C. Bohn, D. Bullard, D. Douglas, A. Grippo, J. Gubeli, G. A. Krafft and B. Yunn: Nucl. Instr. \& Meth. A, 475 (2001) 549.

49) R. Nagai, R. Hajima, N. Nishimori, T. Muto, M. Yamamoto, Y. Honda, T. Miyajima, M. Kuriki, H. Iijima, M. Kuwahara, S. Okumi and T. Nakanishi: Proc. of IPAC10, (2010) 2341.

50) F. Furuta, T. Nakanishi, S. Okumi, T. Gotou, M. Yamamoto, M. Miyamoto, M. Kuwahara, N. Yamamoto, K. Naniwa, K. Yasui, H. Matsumoto, M. Yoshioka and K. Togawa: Nucl. Inst. \& Meth. A, 538 (2005) 33.

51) R. Nagai, R. Hajima, N. Nishimori, T. Muto, M. Yamamoto, Y. Honda, T. Miyajima, H. Iijima, M. Kuriki, M. Kuwahara, S. Okumi and T. Nakanishi: Rev. Sci. Instr., 81 (2010) 033304.

52) K. Togawa, T. Shintake, T. Inagaki, K. Onoe, T. Tanaka, H. Baba and H. Matsumoto: Phys. Rev. ST Accel. Beams, 10 (2007) 020703.

53) T. Tanaka, H. Tanaka, K. Togawa, T. Hara, M. Yabashi, T. Fukui, A. Higashiya, N. Hosoda, T. Inagaki, S. Inoue, M. Kitamura, H. Maesaka, M. Nagasono, T. Ohshima, Y. Otake, T. Sakurai, K. Shirasawa, T. Asaka, T. Hasegawa, H. Ohashi, S. Takahashi, S. Tanaka, T. Tanikawa, H. Kitamura, T. Ishikawa and T. Shintake: Proc. of FELO8, (2008) 537.

54) T. Tajima and J. Dawson: Phys. Rev. Lett., 43 (1979) 267.

55) S. P. D. Mangles, C. D. Murphy, Z. Najmudin, A. G. R. Thomas, J. L. Collier, A. E. Dangor, E. J. Divall, P. S. Foster, J. G. Gallacher, C. J. Hooker, D. A. Jaroszynski, A. J. Langley, W. B. Mori, P. A. Norreys, F. S. Tsung, R. Viskup, B. R. Walton and K. Krushelnick: Nature, 431 (2004) 535.

56) J. Faure, Y. Glinec, A. Pukhov, S. Kiselev, S. Gordienko, E. Lefebvre, J.-P. Rousseau, F. Burgy and V. Malka: Nature, 431 (2004) 541.

57) C. G. R. Geddes, Cs. Toth, J. van Tilborg, E. Esarey, C. B. Schroeder, D. Bruhwiler, C. Nieter, J. Cary and W. P. Leemans: Nature, 431 (2004) 538. 